\title{
Contraceptives, counselling, and pregnancy in women with sickle cell disease
}

\author{
Richard J Howard, Catherine Lillis, Susan M Tuck
}

Sickle cell disease is listed in the manufacturers' data sheets in the United Kingdom as a contraindication to the use of most combined contraceptive pills; the result is confused advice on family planning to a group of women who are at substantial risk from both planned and unplanned pregnancy. A study in north London on the use of contraceptives by women with sickle cell disease indicates that the use of combined oral contraceptives is common. Although medical staff usually advised against pregnancy, such advice was almost always ignored. Over half of the women surveyed had some knowledge about antenatal diagnosis. Family planning advice should be an integral part of the care of women with sickle cell disease. In the absence of specific data to the contrary all methods of contraception may be considered, although with appropriate caution.

Pregnancy is a considerable undertaking for women with sickle cell disease as it is associated with increased maternal and fetal mortality and morbidity.' Contraceptive use is therefore an important part of health care for these women; of the widely used methods of contraception, however, there are uncertainties over the safety of two of them. The combined oral contraceptive pill has been reportedly associated with increased thrombotic risks, ${ }^{234}$ and several authors have cautioned against the use of the intrauterine device. ${ }^{25}$ Sickle cell disease is listed in the manufacturers' data sheets in the United Kingdom as a contraindication to the use of many combined oral contraceptive and postcoital contraceptive pills. Because of the severe risks of pregnancy in these women, however, it has been suggested that sickle cell disease should only be a relative contraindication to the use of combined oral contraception. ${ }^{6}$ Sickle cell disease has been considered not to be a contraindication to the use of injectable progestogens (for example, medroxyprogesterone acetate) or the progestogen only pill, and they are widely used in Jamaica.?

There is a lack of information on the use of contraceptives among women with sickle cell disease in the United Kingdom, and this is felt to mirror the had been explained by the woman's haematologist or sickle cell counsellor. Each woman was asked about her menstrual history, obstetric and gynaecological history, and current and past contraceptive use and problems. The same women were asked firstly, whether anyone had advised them against pregnancy and if so who and had this affected their plans; secondly, if their partner carried sickle cell trait what was the risk of producing a child with sickle cell anaemia; and thirdly, if they were aware of antenatal diagnosis-for example, chorionic villus sampling, amniocentesis, or cord blood sampling by ultrasound guidance.

Because of the confidential and anonymous nature of the interviews it was not possible to corroborate the women's reports by reference to their hospital medical records. All symptoms and complications given are thus taken from the accounts of the women themselves. Ethical committee approval was obtained from all participating hospitals. Every effort was made to conduct the survey in as culturally sensitive a manner as possible with the hope of avoiding previously notorious connotations raised by the suggestion of fertility control in these ethnic groups.

\section{Results}

A total of 164 women were asked to take part in this study and eight refused. Forty two women with sickle cell haemoglobin $\mathrm{C}$ disease (HbSc disease), 12 women with sickle thalassaemia disease (HbS $\beta$ thalassaemia), and 102 women with homozygous sickle cell disease (HbSS disease) agreed to participate. One hundred and forty nine were sexually active. The age range of the 156 women was $17-53$, and the mean was 28.4 years. The average age of menarche was 15 years.

\section{REPRODUCTIVE PATTERNS}

There were a total of 207 pregnancies reported from 100 of these women. Sixty one pregnancies were planned, 133 were unplanned, and data were missing in 13. Thirty one pregnancies miscarried ( 25 women), and 39 pregnancies were terminated for medical or social reasons ( 31 women). One hundred and thirty seven pregnancies went beyond 28 weeks ( 78 women).

\section{CONTRACEPTIVE PRACTICES.}

The table shows the numbers of women using the combined contraceptive pill, the progestogen only pill, the intrauterine device, and injectable progestogens (for example, Depo-Provera) with the reported side effects. In those women using the combined contraceptive pill four complained of increased crises (three had homozygous sickle cell disease and one had sickle thalassaemia), and two women reported deep vein thrombosis. The type of pill was not stated but both were assumed to be low dose preparations because of the prescribing policy of the clinic concerned. Both \author{
confused state of family planning advice provided for \\ these women. We investigated use of contraceptives \\ and complications in women with sickle haemoglobino- \\ pathies. We also assessed the effect of pregnancy \\ counselling and the understanding of inheritance \\ patterns and techniques of antenatal diagnosis.

\section{Subjects and methods} \\ A detailed questionnaire was administered by confi- \\ dential personal interview by a research midwife (CL) \\ to all women with sickle cell disease known to the \\ haematology departments and sickle cell centres of \\ north London. Each woman was visited at her local \\ hospital or at home after the object of the survey \\ Correspondence to: \\ Mr Howard. \\ BMF 1993;306:1735-7 \\ Oniversity Depa
Obstetrics and
Gynaecology, R \\ NW3 2QG \\ research fellow \\ Susan M Tuck, consultan \\ obstetrician and \\ gynaecologist
}

BMJ VOLUME 306

26 JUNE 1993 
Information on contraceptive use in 149 women with sickle haemoglobinopathies

\begin{tabular}{|c|c|c|c|c|}
\hline Factor & $\begin{array}{c}\text { Combined oral } \\
\text { contraceptive } \\
(n=67(45 \%) \\
\left.148 \text { women years }{ }^{\star}\right)\end{array}$ & $\begin{array}{c}\text { Progestogen only pill } \\
(\mathrm{n}=30(20 \%) \\
\left.77 \text { women years }^{\star}\right)\end{array}$ & $\begin{array}{c}\text { Intrauterine } \\
\text { contraceptive } \\
\text { device } \\
(n=28(19 \%) \\
\left.140 \text { women years }{ }^{\star}\right)\end{array}$ & $\begin{array}{c}\text { Injectable } \\
\text { progestogen } \\
\text { (Depo-Provera) } \\
(\mathrm{n}=26(17 \%) \\
44 \text { women years }) \\
\end{array}$ \\
\hline $\begin{array}{l}\text { Side effect: } \\
\text { Irregular bleeding } \\
\text { Dysmenorrhoea } \\
\text { Menorthagia } \\
\text { Oligomenorrhoea/ } \\
\text { amenorhoea } \\
\text { Weight gain } \\
\text { Nausea } \\
\text { Infection } \\
\text { Forgot } \\
\text { Headaches } \\
\text { Migraine } \\
\text { Deep vein thrombosis } \\
\text { Increased crises } \\
\text { Depression } \\
\text { Failures of contraception } \\
\text { Discontinued for side } \\
\text { effects }\end{array}$ & $\begin{array}{c}11(16 \cdot 4 \%) \\
9(13 \cdot 4 \%) \\
\\
7(10 \cdot 4 \%) \\
5(7 \cdot 4 \%) \\
1(1.49 \%) \\
2(2.9 \%) \\
4(5.9 \%) \\
1(1.49 \%) \\
15 \\
8\end{array}$ & $\begin{array}{l}1(3 \cdot 3 \%) \\
3(10 \%)\end{array}$ & $\begin{array}{l}1(3 \cdot 57 \%) \\
6 \\
\text { none }\end{array}$ & $\begin{array}{l}8(30 \cdot 8 \%) \\
4(15 \cdot 4 \%) \\
5(19 \cdot 2 \%) \\
1(3 \cdot 8 \%)\end{array}$ \\
\hline
\end{tabular}

*Total length of time all women had been using method of contraception

had homozygous sickle cell disease. One was aged 28 and had used the pill for one year; she had gall stones and chronic leg ulcers resulting from her sickle cell disease. The other was aged 37 and had used the pill for three years and was otherwise in good health.

Barrier contraception was used at some time by 63 women and the expected problems of discomfort, inconvenience, and messiness were reported. There were nine contraceptive failures. Fourteen women had undergone sterilisation.

\section{COUNSELLING}

We found that of the 149 sexually active patients, 54 had been advised against pregnancy. Forty nine were so advised by medical staff - that is, from haematology, gynaecology, and family planning clinics or from their general practitioner. Despite this advice only three women said that this either had or would influence their plans regarding pregnancy. Of the three, one woman was sterilised at the age of 23 with severe regrets, and two women reluctantly followed the advice given. Only 44 women were correct in their understanding of inheritance patterns in sickle cell disease, and 94 women were aware of the possibility of antenatal diagnosis for sickle cell disease.

\section{Discussion}

COUNSELLING AND UPTAKE OF ANTENATAL DIAGNOSIS

An estimated 150 infants are born with sickle cell disease in the United Kingdom annually. ${ }^{8}$ Efforts to reduce this presuppose that patients should be well informed about the condition and will elect to have prenatal diagnosis and termination of an affected fetus. This ignores the complex issues in sickle cell disease, which is often compared misleadingly with $\beta$ thalassaemia major. This is acknowledged to be a more severe condition in which aggressive counselling and prenatal diagnosis programmes will reduce the number of affected infants born. ${ }^{9}$

Our finding that only $28 \%$ of women with sickle cell disease were correct in their understanding of the inheritance pattern for sickle cell disease probably indicates that the question asked was too difficult. We are encouraged that $60 \%$ had heard of antenatal diagnosis, suggesting that awareness of genetic transmission to offspring is higher.

Factors influencing a couple's decision to take up antenatal diagnosis are complex. One study of couples with sickle cell trait in north London showed that those who were offered prenatal diagnosis but refused it tended not to have been informed about sickle cell disease before counselling or they had no existing children with sickle cell disease or had children who were not severely affected. ${ }^{10}$ Other factors influencing their decision included a poor obstetric history and rejection of abortion, mainly on moral grounds. Data from North America ${ }^{11}$ and the United Kingdom ${ }^{10}$ show that prenatal diagnosis is requested by only about half of those couples identified as at risk, and even when prenatal diagnosis indicates sickle cell disease termination is not always requested. ${ }^{11}$

\section{CONTRACEPTIVE USE}

We found that $45 \%$ of all women had used the combined contraceptive pill at some time, with $19 \%$ having used the intrauterine device. This is similar to results from North America where it was found that $39 \%$ used the combined contraceptive pill and $15.4 \%$ used the intrauterine device. ${ }^{12}$ Most authors have now concluded that the intrauterine device is safe in women with sickle cell disease ${ }^{3713}$; the theoretical risk of endometritis and tube ovarian abscess with the added possibility of provoking sickling crises, which has been cited by some workers, ${ }^{25}$ has not been proved. There are more data on the use of injectable progestogensfor example, Depo-Provera-and several authors have reported on its safety. ${ }^{4514}$ Of the 26 women in our series who had used injectable progestogens there were no reports of serious side effects.

Our finding of two women with a history of a deep vein thrombosis when taking the contraceptive pill is disturbing. Both gave a history to the researcher of admission to hospital and anticoagulation, but we were unable to verify this from hospital records because of the confidential nature of the study. Reports available on the safety of the combined contraceptive pill are contradictory, with some authors stating that thrombosis, tissue infarction, and sickling may be increased by the oestrogen component. ${ }^{2{ }^{34}}$ This view is not universal with others concluding that combined oral contraceptives are safe in women with sickle cell disease. ${ }^{131516}$ There have been two case reports of women with sickle cell trait who had thromboembolism while taking the combined contraceptive pill. ${ }^{17}{ }^{18}$ No convincing case is made, however, to justify the implication that their sickle cell trait had any relevance. There has also been a report of two women with sickle cell haemoglobin $\mathrm{C}$ disease who had pulmonary infarction while taking the combined contraceptive pill. ${ }^{19}$ The report does not in fact provide evidence, however, to justify the conclusion that this was a thromboembolic infarction as opposed to pulmonary sickling or infection, or both. All these women were taking high dose pills, and we can find no reports of thrombosis on modern low dose pills. We feel that such case reports may have unwittingly generated the current widespread confusion among practitioners on this issue.

We also found that four women had increased crises while on the contraceptive pill, and there are few other reports of this. One 10 year study of 71 patients with sickle cell anaemia who were on contraceptives containing oestrogen indicated that there were no adverse effects on the clinical course of these women with only one having possibly related sickling crises. ${ }^{16}$

\section{REPRODUCTIVE PATTERNS}

The high rate of unplanned pregnancy in this group of women would suggest that the use of contraceptives is far from adequate. Our finding that one third have been advised against pregnancy contrasts with the evident lack of effective advice on contraception shown by the rate of unplanned pregnancy of $64 \cdot 2 \%$. This is higher than that reported by a previous similar study, in which the rate was $38 \% .{ }^{12} \mathrm{~A}$ weakness of our study is acknowledged in the lack of a control population to assess rates of unplanned pregnancy in the general 
population; a previous report, however, suggests it is around $32 \%{ }^{20}$ Many of these unplanned pregnancies will be terminated; in our study the figure of $19 \%$ agrees with evidence to suggest that one in five pregnancies are terminated in the United Kingdom. ${ }^{21}$

\section{Conclusion}

The confused medical awareness of which contraceptive methods are appropriate may partly explain why advice to women with sickle cell disease is often lacking. We cannot exclude a possible risk of crises and thrombotic episodes with the use of the combined contraceptive pill. Despite this, we do not consider it to be contraindicated in this group of women as any complications should be balanced against the substantial risks of pregnancy. We feel that all methods of contraception may be considered in women with sickle haemoglobinopathies, though with appropriate caution.

We gratefully acknowledge generous financial support from SCAR (Sickle Cell Anaemia Relief) and the invaluable cooperation of the North London Haemoglobinopathy Group and the Sickle Cell Centres of north London.

1 Tuck SM, Studd JWW. Pregnancy in sickle cell disease in the UK. Br f Obstet Gynaecol 1983;90:112-7.

2 Foster HW. Contraceptives in sickle cell disease. South Med f 1981;74:543-5.

3 Evans DIK. Sickle cells and hormonal contraception. British foumal of

Family Planning 1984;10:80-1.
4 Perkins RP. Contraception for sicklers. N Engl f Med 1971;285:296.

5 Morrison JC. Hemoglobinopathies and pregnancy. Clin Obstet Gynecol 1979;22:819-42.

6 Louden N, ed. Handbook of family planning. 2nd ed. London: Churchill Livingstone, 1991

7 Sergeant GR. Sickle haemoglobin and pregnancy. BMJ 1983;287:628-30.

8 Petrou M, Modell B, Darr A, Old J, Kin E, Weatherall D. Antenatal diagnosis. How to deliver a comprehensive service in the United Kingdom. Ann N Y Acad Sci 1990;612:251-63.

9 Loukopoulos D, Hadji A, Papadakis M, Karababa P, Sinopoulou K, Boussiou $\mathrm{M}$, et al. Prenatal diagnosis of thalassaemia and of the sickle cell syndromes in Greece. Ann N Y Acad Sci 1990;612:226-36.

10 Anionwu EN, Patel N, Kanji G, Renges H, Brozovic M. Counselling for prenatal diagnosis of sickle cell disease and thalassaemia major: a four year experience. $\mathcal{F}$ Med Genet 1987;25:769.

11 Rowley PT, Loader S, Sutera CJ, Walden M, Kozyra A. Prenatal screening for haemoglobinopathies. I. A prospective clinical trial. Am $f$ Hum Genet $1991 ; 48: 439-46$

12 Samuels-Reid JH, Scott RB, Brown WE. Contraceptive practices and reproductive patterns in sickle cell disease. I Natl Med Assoc 1984;76: 879-83.

13 Charache S, Niebl JR. Pregnancy and sickle cell disease. Clin Haemato 1985;14:729-46.

14 De Ceulaer K, Gruber C, Hayes R, Serjeant GR. Medroxyprogesterone acetate. and homozygous sickle cell disease. Lancet 1982;ii:229-31.

15 Freie HMP. Sickle cell diseases and hormonal contraception. Acta Obste Gynecol Scand 1983:62:211-7.

7. sickle cell disorders-fact or fiction? Clin Res 1986;34:217A.

17 Greenwald JG. Stroke in a woman with sickle cell trait taking oral contraceptoves. Conn Med 1971;35:231-2.

18 Hargus EP, Shearin R, Colon AR. Pulmonary embolism in a female adolescen with sickle cell trait and oral contraceptive use. Am $\mathcal{F}$ Obstet Gynecol 1977;129:697-9.

19 Haynes RL, Dunn JM. Oral contraceptives, thrombosis, and sickle cell haemoglobinopathies. IAMA 1967;200:186-8

20 Fleissig A. Unintended pregnancies and the use of contraception: changes from 1984 to 1989 . BMF 1991;302:147.

21 Smith T. Unwanted pregnancies. BMF 1990;300:1154

(Accepted 8 April 1993)

\title{
Why have child pedestrian death rates fallen?
}

\author{
Ian Roberts
}

Pedestrian injuries are a leading cause of childhood mortality and disability. Over the past two decades in Britain child pedestrian death rates have fallen despite large increases in traffic volume. In this paper Roberts examines the likely reasons for this decline. He argues that neither prevention programmes nor improvements in medical care are a plausible explanation and that the decline is most likely the result of a substantial reduction in children's traffic exposure. He believes, however, that restricting children's traffic exposure exacerbates socioeconomic differentials in childhood mortality and denies children their right to mobility. Roberts is convinced that one answer is for British transport policy to be aimed at providing mobility equitably rather than struggling to meet the ever increasing demands of car travel.

Between 1980 and 1990 in England and Wales an average of 239 children were killed each year on the roads as pedestrians. For every death around 10 children required hospital admission for injuries. Pedestrian injuries were among the leading causes of childhood admission to intensive care facilities. ${ }^{2}$ Between $60 \%$ and $80 \%$ of these children have severe head injuries and are likely to experience long term disability. ${ }^{1}$

With the more widespread recognition of the public health importance of child pedestrian injuries in recent years several epidemiological studies have been mounted aimed at identifying modifiable risk factors. These studies have used case-control or cohort methods in an attempt to identify the factors which place some children at high risk of pedestrian injury. ${ }^{46}$ However, an effective public health response to the problem of child pedestrian injury demands that a second aetio- logical issue should be addressed. This concerns the identification of determinants of the incidence, attempting to understand why child pedestrian death rates change over time. Answering this question is likely to be as important as identifying risk factors, because if the determinants of the incidence could be identified it might be possible to control them, with gains for the whole child population. ${ }^{?}$

Over the past two decades child pedestrian death rates have fallen in many developed countries. In England and Wales between 1968 and 1987 the pedestrian mortality among children aged 0.4 years fell by $67 \%$, and among children aged $5-14$ years it fell by $39 \% .{ }^{8}$ To gain an insight into why child pedestrian death rates have fallen changes in the potential determinants of the child pedestrian death rate must be considered.

\section{Potential determinants of child pedestrian deaths}

The determinants of incidence are most readily identified when their prevalence changes abruptly. For this reason the effect of traffic volume on child pedestrian mortality was most evident during the energy crisis, when an increase in the price of petrol had a measurable effect on the growth in traffic volume. In New Zealand government restrictions on car use in the aftermath of the energy crisis effectively arrested the growth in traffic volume for seven years, during which there was a $46.4 \%$ reduction in child pedestrian mortality. ${ }^{9}$ Before this the death rate had been increasing in parallel with increasing traffic volumes. That the rate fell, as opposed to levelling off in line with traffic volume, suggests that there were other processes operating, tending to reduce the mortality, but which became evident only when traffic 